\title{
Technology-based Educational Portfolio
}

\author{
Eunjoo Oh \\ Kyungil University \\ eoh1@hanmail.net
}

\begin{abstract}
Portfolio is a collection of works that focuses on the specific areas of learning. That is an effective way of showing the progress of students' learning. This study was to find out whether educational portfolios help preservice teachers with their technology skills and teaching practices. To achieve the study goals, the survey instrument was developed by the research and reviewed by three professors in the field of educational technology to confirm the reliability. It consists of three sections with 26 questions with 5 Liker scales. The survey was conducted with the two groups of preservice teachers. One group had experiences with developing portfolios while the other grôp did not have any experiences with portfolios. The class was designed to gchreve the technology skills while developing the multimedia- based portfolio. The technology applications that students had to learn included PowerPoint, Excel, Moviemaker, 'Cam, Compozer and free-mind. According to the study results, the group with portfolio experiences had higher technology skills and more positive perception of teaching and learning practices. Based on the study results, the items that should be included in the educational portfolios were suggested and effective ways of using portolio were discussed.
\end{abstract}

Keywords: Instructional Techn@10gy, Portfolios, Education, Teachers, Instruction

\section{Introduction}

\subsection{Background}

Historically, technology has played a critical role in the development of society. Each developmental stage of society (t.e. agricultural, industrial, and information society) has been initiated and stimulated by technology and knowledge-related activities. Technology has also had a great impact on educational systems in both teaching and learning practices. In particular, various instructional methods and curriculum reforms based on instructional media and technology has been introduced and contributed to improving learning and clàssroom environments [3-4].

Portfolio is a collection of works that focuses on specific areas of learning. In the study areas suen as arts and architectures, it is common for students to develop their portfolios through the years of study to prove their performance levels. Portfolios are effective ways to show the progress of students' learning and levels of performance and thus it is often used for assessment [6]. Through the years, the form of portfolios has changed from paper-based portfolios to computer-based portfolio known as e-portfolio, web-based portfolio, and multimedia-based portfolio. As the use of technology is increasing, many universities started to develop web-based portfolio systems and made as a graduation requirement in certain areas [7].

Nowadays, many universities provide web-based portfolio systems for students to create their e-portfolio. In particular, teacher education programs in the United States encourage students to develop their teaching portfolio. Teaching portfolio is a collection of works that contain evidence of learning achievement and teaching experiences. The primary aim of a teaching portfolio is to improve quality of teaching by providing a 
structure for self-reflection that contains the evidence of their learning achievement and teaching experiences.

Preservice teachers have to prove that they meet the state standards and learning outcomes such as teacher-made learning materials and lesson plans are included in the portfolio as an evidence of achievement. Teaching portfolio is being used for preservice teachers or teachers for licensure. Studies about portfolio advocate that developing a portfolio facilitates students' learning in a way that students reflect their learning practices when they arrange their works into the portfolio system. The studies also reveal that portfolios can improve students' ability to integrate theory with practice [4] and many teacher education programs require preservice teachers to submit educational portfolios as a fulfillment for graduation. The use of portfolio in undergraduate settings provided students with insights about their learning activities [5-6].

Cognitive theory of multimedia learning shows that people learn better and more deeply from words and pictures than from words alone[8]. Multimedia is a combination of text, pictures, sounds, and videos and it is effective to maximize learning aetivities. Multimedia-based portfolio is a portfolio that a variety of technology is used. However, teaching portfolio for preservice teachers is not common in Korea. Since the national exam is necessary for acquiring the teaching license, developing portiolio is not considered as an important learning activity in schools. However, considering the fact that the portfolio is a meaningful learning activity for preservice teache to reflect their teaching experiences and insight of teaching practices as a perspectiveteacher [3].

\subsection{Portfolio in Education}

Portfolio is a collection of works through the process of students' participation in the education program. Educational portfolion is a systematid learning management program and self-reflection program that contains the history of students from the admission to graduation from the teacher education program. While developing portfolios, students have an opportunities to look into their insigh and find their own characteristics and tendencies about learning in general [2,10]. Understanding about themselves help them to set up the goals for school life and future directions after graduation. Understand about themselves and setting up the right objectives for the study are important for students because it affect the quality of their school lives, and competencies that they will achieve after finishing the program. During the course of the program, recording their learning outcomes and developing teaching materials help not to lose their identity as a future teacher as well $[5-4]$.

Looking at the portfolio as a reflection tool, portfolio means a holistic evaluation method; through the Qemester, students record their ideas, works, knowledge, skills, interesting things and outcomes in the scrapbook and teachers can evaluate students' performance in various aspects. Recording the entire activities makes possible for the teachers to examine the process of development of the students comprehensively and enhance their learning by writing the feedback in the portfolio [1]. Students also write self-reflective statements about their works in the portfolio. Since the portfolio includes teachers' comments and students' self-reflection, it is valuable in both teaching and learning practice, connecting teachers and students in a meaningful way [8].

In that aspect, portfolio is an efficient assessment tool. Since it may include selfassessed reflections, peer-reviews, and teacher assessment, it can be an efficient assessment tool for emphasizing the educational values In addition, portfolio can be used as one of the effective teaching strategies to enhance the self-directed learning skills while increasing the levels of students' responsibility for achieving their learning objectives. Portfolio provides student-centered learning environments. The students themselves find their own study levels and needs to decide what they have to do for completing the tasks. While working on the portfolio, they develop their own strategies to use the technology 
tools and focus on the learning objectives $[7,10]$. The concept of portfolio in education is in Figure 1 below.

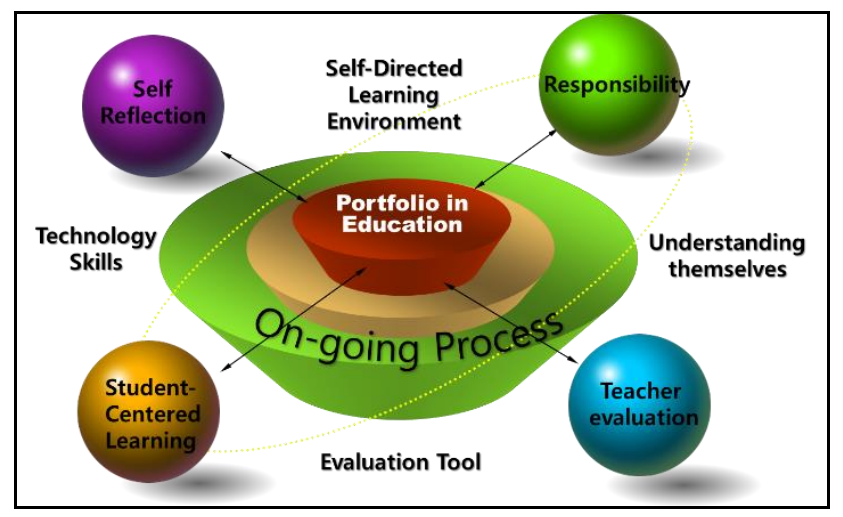

Figure 1. Concept of Portfolio

\subsection{Problem Statement}

The teacher education program should prepare preservice teachers to have sound perspectives about educational values and attitudes towards teaching. In addition, the programs have to make them to have enough skills and knowledge for developing their own teaching methods and teaching materials with technology tools. In order to do that, the students must have experiences to develop a teaching portfolio. As mentioned above, teaching portfolio is a collection of works and reflections about teaching practices. Developing a multimedia-based teraching porffolio will help preservice teachers in achieving the knowledge and skills necessary. However, there are not many studies conducted focusing on multimedia-based ecueational portfolios in the field of teacher education. Therefore, it will be meaningfun to design and implement a portfolio class.

\subsection{Purposes of the Study}

The purposes of this study were to find out whether teaching portfolios help preservice teachers with their technology skils and teaching practices, and find the items that should be included in the teaching portfolio. Based on the study results, portfolio items and effective ways of using porffolio were suggested.

\subsection{Research Questions}

In order to achieve the study goals, three research questions were proposed as follows:

1. How do preservice teachers perceive a teaching portfolio?

2. Does teaching portfolio help preservice teachers' with their technology skills?

What kind of items should be included in the teaching portfolio?

\section{Methodologies}

\subsection{Research Methods}

At the beginning of the semester, two education classes were selected. In one class, educational portfolios were taught while there was not any portfolio lessons in the other class. The students in the class developed their educational portfolios throughout the semester. After the semester was over, surveys were conducted with the two groups of students to compare their perceptions and technology skills. 


\subsection{Research Participants}

Total 48 students in the teacher education program participated in the survey. All of them were seniors who had teaching experiences in the secondary schools. Among the total participants, 20 students took the portfolio class and 28 students did not. Detailed information about the participants is as Table 1 below.

Table 1. Research Participants

\begin{tabular}{|l|l|l|}
\hline & $\begin{array}{l}\text { With portfolio } \\
\text { experience }\end{array}$ & $\begin{array}{l}\text { Without portfolio } \\
\text { experiences }\end{array}$ \\
\hline Engineering & $\mathbf{0}$ & $\mathbf{1 0}$ \\
\hline Arts & $\mathbf{0}$ & $\mathbf{1 0}$ \\
\hline Science Education & $\mathbf{2 8}$ & $\mathbf{0}$ \\
\hline & $\mathbf{2 8}$ & $\mathbf{2 0}$ \\
\hline
\end{tabular}

\subsection{Research Instrument}

The survey instrument was developed by the research and reviewed by three professors in the field of educational technology to confirm the reliability. It consists of three sections with 26 questions with 5 Likert scales. Section one asked the perceptions of portfolios, section two asked the technology competencies, and the third section asked the items that should be included in the educational portfolios. The reliabilities of each section were $0.88,0.92$, and 0.87 . Detailed information about the survey instrument is presented in Table 2 below.

\subsection{Data Analysis}

The survey results were analyzed using SPSS 21. Descriptive statistics were used to measure the levels of technology competencies and the students' perceptions about the teaching portfolio. The independent T- test was conducted to compare the answers based on the experiences with the portfolio, gender, and majors.

\section{Class Design}

The class was designed to achieve the technology skills while developing the multimedia- based portfolio. The technology applications that students had to learn to develop the portfolio included PowerPoint, excel, moviemaker, o'Cam, Compozer, and free-mind. The artifacts included educational philosophy, teaching materials, teaching experience, and various learning evidence. According to the syllabus, students learnt how to develop the portfolio items along with the necessary technology skills every week. Detailed information about the class design and the portfolio templet are presented in Figure 1 and 2 below. 


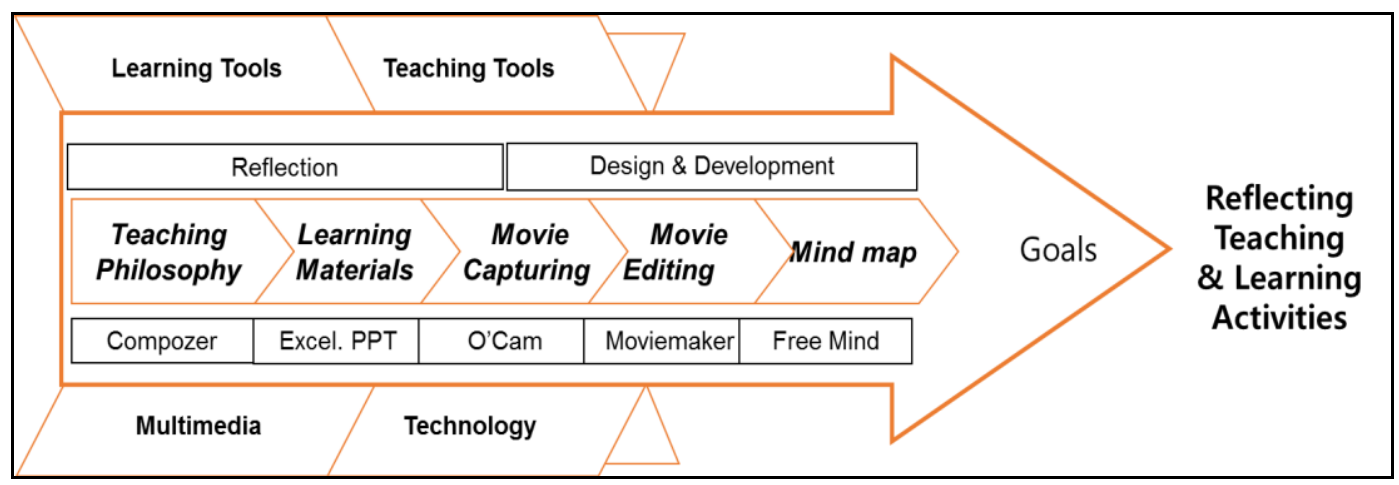

Figure 2. Class Design

\section{Educational Portfolios}

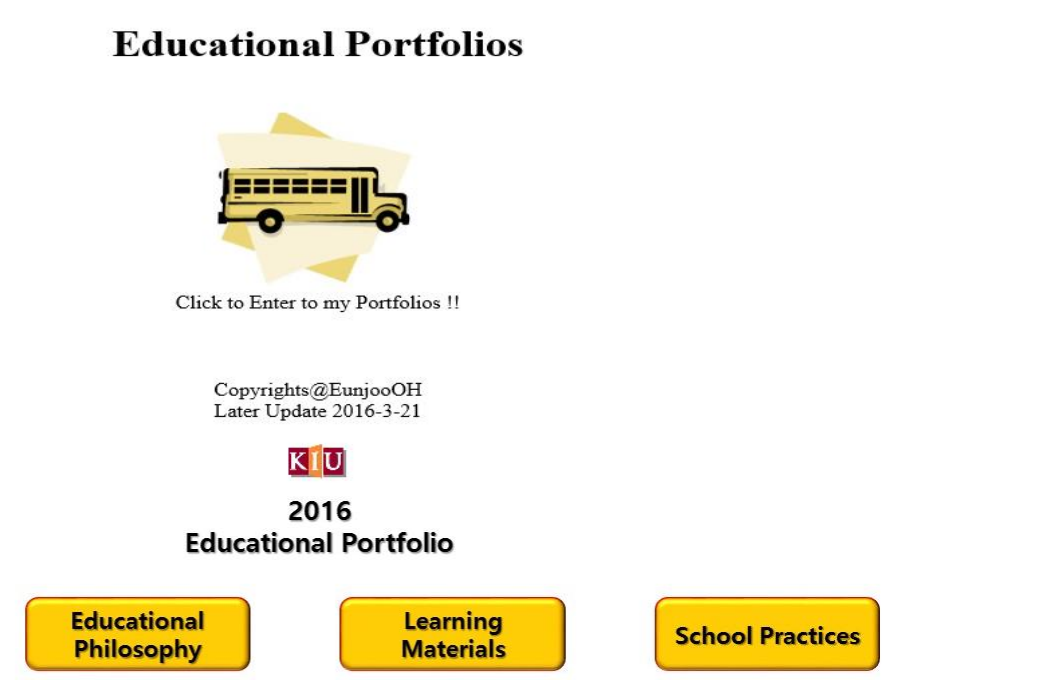

\section{Study Results}

\subsection{How do Preservice Teachers Perceive Teaching Portfolios?}

When analyzing the perceptions of the teaching portfolio, there was a difference in their answers between the groups. The group who took the portfolio class showed more positive attitudes towards the effectiveness and necessity about the portfolio ( $M=3.84$, $\mathrm{M}=3.5$ ). In particular, two groups showed a big difference about the need of portfolio in the teaching practice $(\mathrm{M}=4.15, \mathrm{M}=3.54)$. The respondents who had a portfolio experience perceived that high levels of technology skills are needed and it is necessary for the teaching job while the other did not perceive in that way. However, both groups agreed that $i t$ is necessary for teachers to integrate technology into the classroom activities in this information society. According to the T-Test, there was not statistical difference about the perceptions between the two groups, however, there was a statistical difference about the perceptions of the necessity of portfolio for getting a teaching job $(\mathrm{P}<0)$. Detailed information is presented in Table 3 and Table 4 below. 
Table 3. Perceptions of Educational Portfolios

\begin{tabular}{|l|l|l|l|}
\hline & Items & $\begin{array}{l}\text { With } \\
\text { experiences }\end{array}$ & $\begin{array}{l}\text { Without } \\
\text { experiences }\end{array}$ \\
\hline 1 & $\begin{array}{l}\text { High levels of technology skills are needed for } \\
\text { developing a teaching portfolio }\end{array}$ & 3.65 \\
\hline 2 & $\begin{array}{l}\text { Educational portfolio is necessary for } \\
\text { preservice teachers. }\end{array}$ & 3.75 & 3.25 \\
\hline 3 & $\begin{array}{l}\text { Educational portfolios helps me increasing } \\
\text { technology skills. }\end{array}$ & 3.75 & 3.43 \\
\hline 4 & $\begin{array}{l}\text { Educational portfolios will help me find a } \\
\text { teaching job. }\end{array}$ & 3.90 & 3.36 \\
\hline 5 & $\begin{array}{l}\text { Educational portfolio is important in my field } \\
\text { of study. }\end{array}$ & 4.15 & 3.54 \\
\hline 6 & $\begin{array}{l}\text { The use of technology enhance students' } \\
\text { learning. }\end{array}$ & 3.8 & 3.5 \\
\hline 7 & $\begin{array}{l}\text { Teachers' ability to use technology effects } \\
\text { students' learning. }\end{array}$ & 3.73 & 3.79 \\
\hline 8 & $\begin{array}{l}\text { It is necessary for teachers to integrate } \\
\text { technology for the classroom activities in this } \\
\text { information society. }\end{array}$ & 4.1 & 3.0 \\
\hline & Total & 3.56 & 3.8 \\
\hline
\end{tabular}

Table 4. T-Test about the Perceptions between the groups

\begin{tabular}{|c|c|c|c|c|c|c|c|c|c|}
\hline \multirow{4}{*}{ Perceptions } & \multirow{2}{*}{\multicolumn{5}{|c|}{$\begin{array}{l}\text { Necessary for the Joi } \\
\text { With experiences } 4 \text { Without } \\
\text { Experiences }\end{array}$}} & \multirow{3}{*}{\multicolumn{2}{|c|}{$\begin{array}{l}95 \% \text { CI for } \\
\text { Mean } \\
\text { Difference }\end{array}$}} & & \\
\hline & & & & & & & & & \\
\hline & $\mathbf{M}$ & SD & n & M SD & $\mathbf{n}$ & & & & \\
\hline & 4.15 & 1.07 & 20 & \begin{tabular}{l|l}
3.54 & 0.62 \\
\end{tabular} & 28 & -1.13 & -0.96 & -2.2 & 46 \\
\hline
\end{tabular}

When analyzing the text about the perceptions, it was found that the respondents perceived that educational portfolios would be effective tools to raise the students' motivation for learning Using the educational portfolios, teachers present their teaching materials on the website and students may review the learning contents in advance. It also helps students' understanding about their teachers and teaching philosophy, and make the connections between the teachers and students. In addition, the respondents emphasized that portfolios vould be utilized in any of the study areas or working areas since it contains a piles of works that show the history of the person. Since the portfolios represent what and how the person has been doing in the field of study, it will help for them to find the job.

\section{Does Portfolio Help Preservice Teachers in Developing their Technology Skills?}

When analyzing the technology competencies, the group $(M=4$. 09) who took the portfolio class showed a higher competency level than the other group $(M=3$. 7). The group who has taken the portfolio class was more competent with using information technology, Excel, and PPT application than the other group. They answered that they are competent with developing teaching materials, pictures, graphs, tables in Excel and PowerPoint. In addition, they were competent in using video editing programs, and developing animations in PPT. In particular, when analyzing the competencies in using information technology, there was a statistical difference between the groups as Table 6 
present $(\mathrm{P}<0)$. However, both groups showed relatively low competencies in troubleshooting and dealing with educational software.

Table 5. Technology Competencies

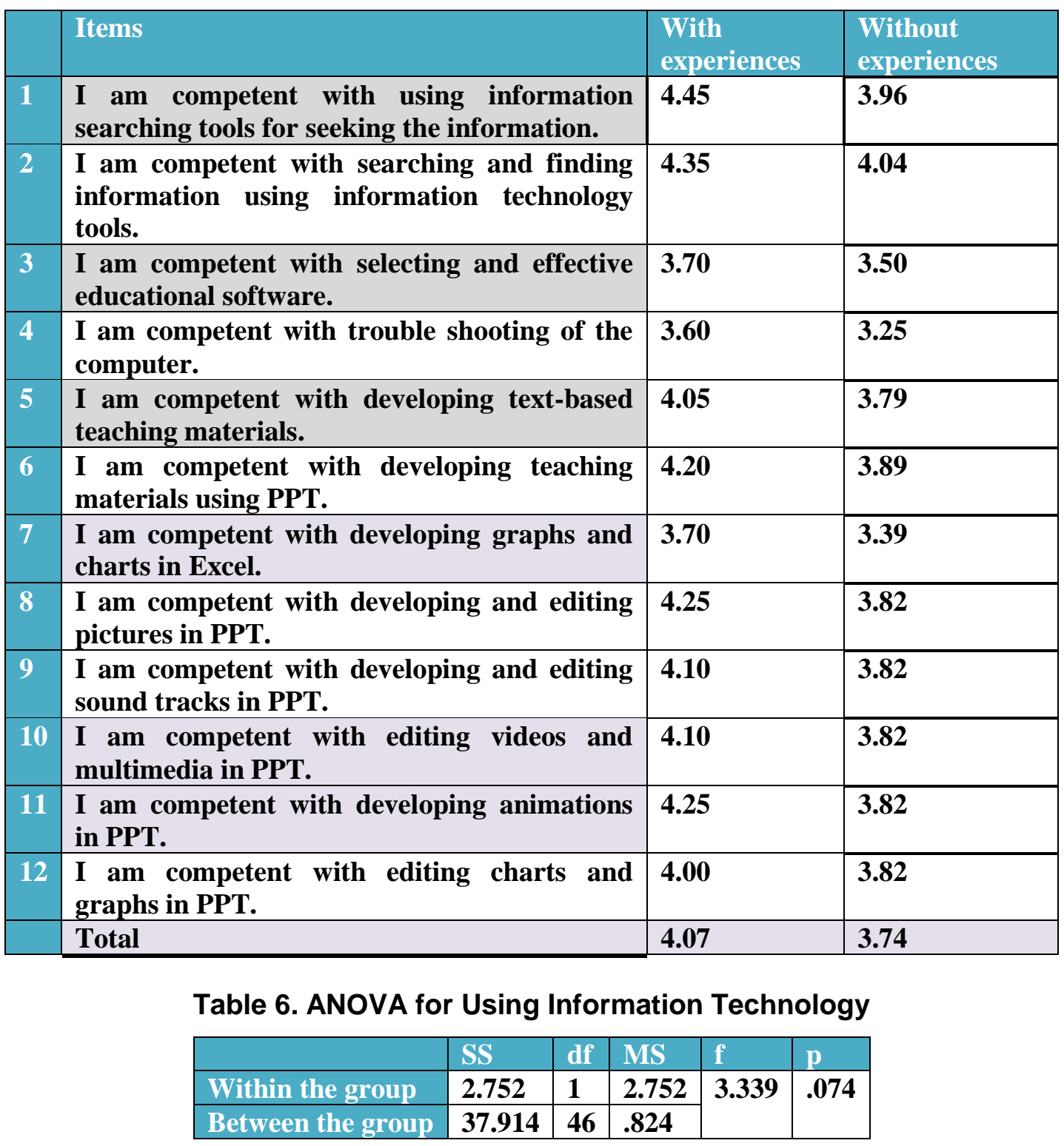

\subsection{Does Portfolio Help Preservice Teachers in Developing their Items?}

When analyzing the data about students' opinions about the items that should be included in teaching values $(\mathrm{M}=4.15)$, teaching portfolio $(\mathrm{M}=4.05)$, teacher-made teaching materials $(M=4.0)$, teaching methods $(M=4.0)$, and learning evidence about the major field of studies $(M=4.0)$. In detail, the group who took the portfolio class more strongly agreed to include the items such as teaching experiences $(M=3.85)$, teaching theories and methods $(M=3.85)$, and learning evidences $(M=4.0)$ than the other group. In the case of evaluation methods, the group who did not have any portfolio experiences $(\mathrm{M}=4.0)$ agreed more strongly than the other group $(\mathrm{M}=3.85)$. When analyzing the differences between the groups, there were a statistical difference about including the evidence of learning from the major field of studies $(\mathrm{P}<0)$ as Table 8 presents. 
Table 7. Suggested Items for Portfolios

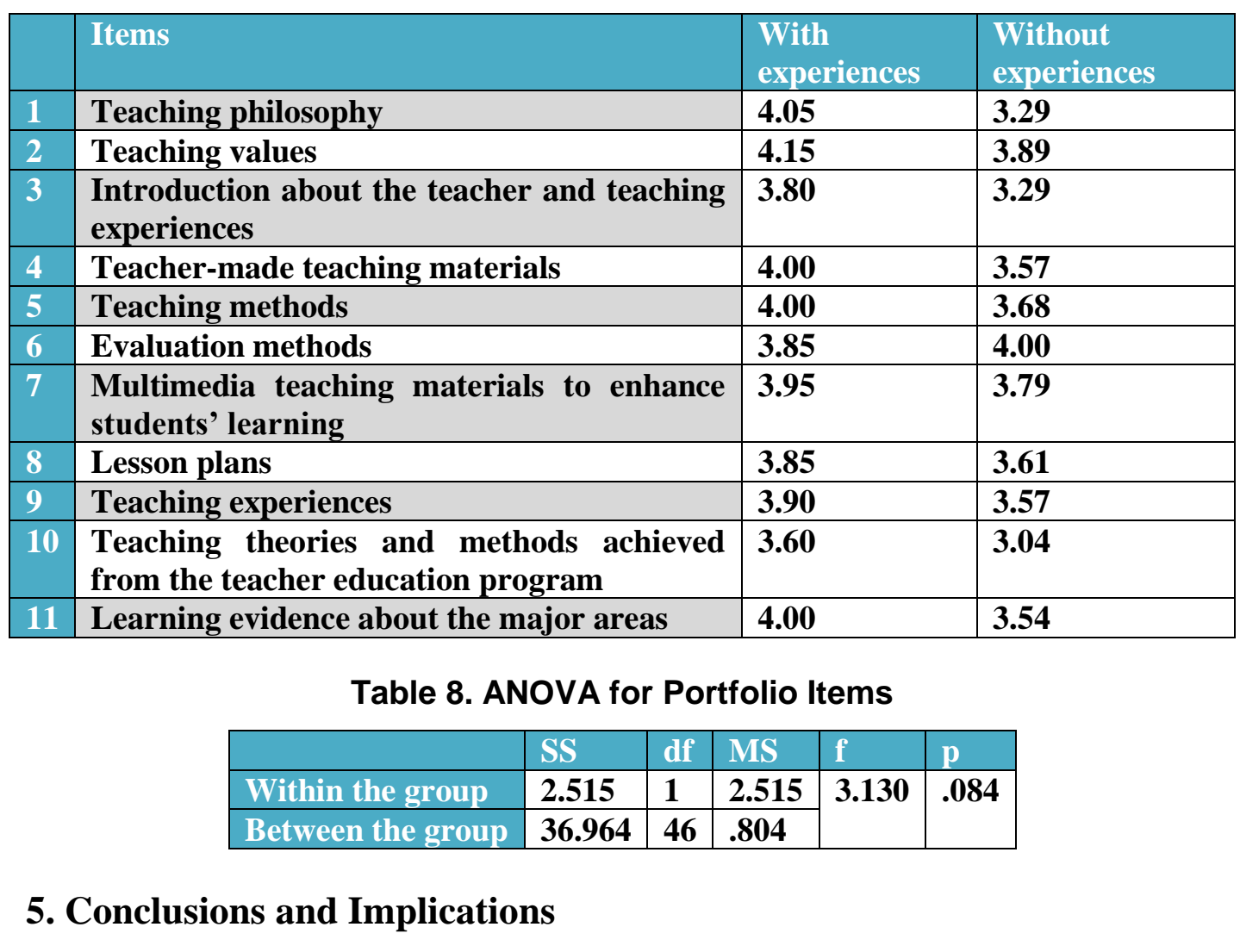

This study attempted to suggest to develop nultimedia based educational portfolios. When analyzing the perceptions of the teaching portfolio, there was a difference in their answers between the groups. The glour who took the portfolio class showed more positive attitudes towards the effectiveness and necessity about the portfolio. In particular, two groups showed a big difference about the need of portfolio in the teaching practice. When analyzing the technology competencies, the group who took the portfolio class showed a higher competeney level than the other group. The group who has taken the portfolio class was more competent with using information technology, Excel, and PPT application than the othergroup. They answered that they are competent with developing teaching materials pictures, graphs, tables in Excel and PowerPoint. When analyzing the data about students' opinions about the items that should be included in teaching values, teaching portfolip, teacher-made teaching materials, teaching methods, and learning evidence about the major field of studies. In detail, the group who took the portfolio class more st ongly agreed to include the items such as teaching experiences, teaching theories and nethods, and learning evidences than the other group.

h summary, developing a teaching portfolio is beneficial for preservice teachers to enbance their skills to develop teaching materials, and provide more chances to reflect their teaching and learning activities. In addition, multimedia-based portfolio helps students increase technology competencies and positive attitudes towards teaching practices. It also helps students' understanding about their teachers and teaching philosophy, and make the connections between the teachers and students. In addition, portfolios would be utilized in any of the study areas or working areas since it contains a piles of works that show the history of the person. Since the portfolios represent what and how the person has been doing in the field of study, it will help for them to find the job. The conceptual figure of educational portfolio is as Figure 3 below. 


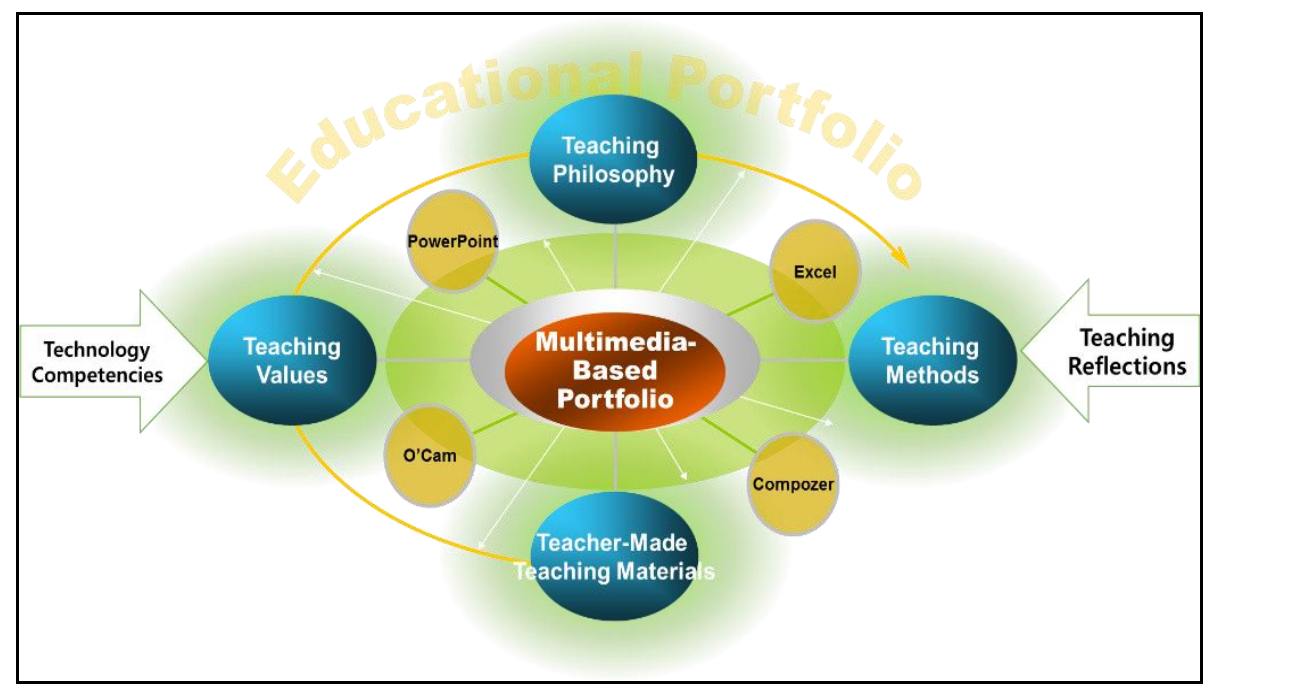

Figure 4. Concept of Educational Portfolio

Based on the study, educational portfolio is an effective teaching and learning tools for preservice teachers, and thus implement the educational portfolio class in to the curriculum. In addition, preservice teachers can enhance their knowledge and skills in technology. Developing educational portfolio is an effective use of instructional technology in the classroom. In particulan multimediatbased portfolio is a good instructional media in a way that it deals with a variety of technology tools connecting the skills and knowledge together. Over the years, instructional technology has been incorporated with learning theories, pedagogy, and learning situations. There have been many attempts to find the relationship between technology and learning about the appropriate use of technology in loproving performance of learning systems. Based on that theoretical background, technology has been used not just as an instructional medium, but also as an integral part of the learning process and enriches classroom environments in many ways

Today, technology contributes to accommodating the diverse needs in education by providing various formats of instructional delivery modes. The most promising roles of educational porfolio can be divided into three categories: (1) improving students' performance, (2) providing tools and environments for designing student-oriented instructional methods, and (3) solving instructional problems, allowing more options in multimedia - based teaching materials. In terms of learning, classroom performance can be improved by utilizing multimedia software, content- based CD-ROMs, and online resources.

When those materials are developed by teachers integrated into the curriculum, it will be more effective learning tools. Well-designed teacher-made learning materials enhanced instruetion is very beneficial to both teachers and students; instruction makes the learning process more enjoyable and memorable while achieving instructional goals. The a ailability of well-developed teaching materials gives teachers and students to have a variety of opportunities to expand the curriculum for various events. Classrooms can be enriched by technology-based instruction when it is well- planned and -designed. Planning and designing is an important process in integrating technology into curriculum. To create an adequate instructional design, learning theories, classroom context, and attributes of technology are combined and embedded in the design process.

Many studies claim that multimedia technology stimulate students' learning while being used as a delivery vehicle or stimuli. In that sense, multimedia-based portfolio plays a role in providing foundations and tools for student-oriented instruction. In general, technology in education provides more options for students and teachers. Those options 
result from the development of technology and the use of technology; the most promising roles of educational portfolio are changing the learning environment providing opportunities for reflections of teaching learning activities while developing the technology skills.

\section{References}

[1] J. Kimura and H. Shibasaki, "Recent Advances in Clinical Neurophysiology", Proceedings of the 10th International Congress of EMG and Clinical Neurophysiology, Kyoto, Japan, (1995).

[2] S. Buckley, J. Coleman and K. Khan, "Best evidence on the educational effects of undergraduate portfolios", The Clinical Teacher, vol. 7, (2010), pp. 187-191.

[3] M. Y. Chen, F. Chang, C. Chen, M. Huang and J. Chen, "Why do Individuals Use e-Portfolios", Educational Technology \& Society, vol. 15, no. 4, (2012), pp. 114-125.

[4] E. Oh, "Developing Multimedia Portfolio for Preservice Teachers", Proceedings of the International Workshops Education 2016, Jeju Island, Korea, (2016).

[5] M. Eskici, "University students' opinions on application of portfolio in higher education", Social and Behavioral Science, vol. 174, (2015), pp. 2646-2655.

[6] R. E. Mayer, "Multimedia learning: Are we asking right questions", Educational Psychologist, vor. 32, (1997), pp. 2-19.

[7] W. Meeus, P. Petegem and E. Nadine, "Validity and reliability of portfolio assessment in pre-service teacher education", Assessment and Evaluation in Higher Education, vol. 34, no. 4 (2009), pp. 401-413.

[8] G. Oakley, M. Pegrum and J. S. Shannon, "Introducing e-portfolios to pre-service veachers as tools for reflection and growth: lessons learnt", Asia-Pacific Journal of Teacher Education, yol. 42, no. 1, (2014), pp. $36-50$

[9] N. S. Sidhu, "The teaching portfolio as a professiona development tool for anesthetists", Anaesth Intensive Care, vol. 43, no. 3, (2015), pp. 328-334.

[10] E. Ucak and S. Kose, "The science preservice teachers opinions related to portfolio files", E-journal of New World Sciences Academy, vol. 4, no. 3, (2009), pp. 920-922.

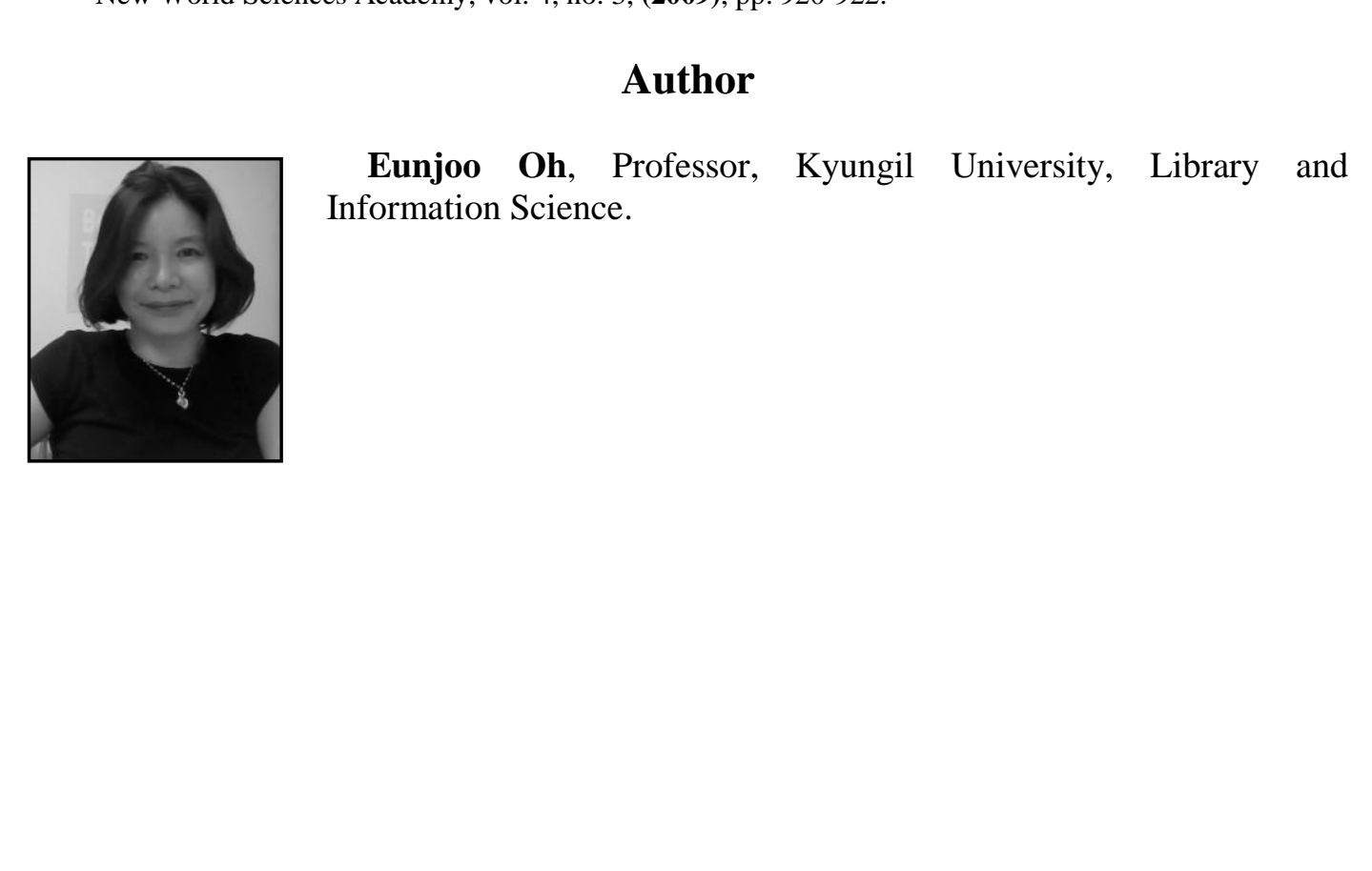

